\title{
The selection between apoptosis and necrosis is differentially regulated in hydrogen peroxide-treated and glutathione-depleted human promonocytic cells
}

\author{
A Troyano ${ }^{1}$, P Sancho $^{1}$, C Fernández ${ }^{1}, \mathrm{E}$ de Blas ${ }^{1}, \mathrm{P}$ Bernardi ${ }^{2}$ \\ and $P$ Aller ${ }^{*, 1}$ \\ ${ }^{1}$ Centro de Investigaciones Biológicas, Consejo Superior de Investigaciones \\ Científicas, Madrid, Spain \\ 2 Department of Biomedical Sciences, University of Padova, Padova, Italy \\ * Corresponding author: P Aller; Centro de Investigaciones Biológicas, CSIC, \\ Velázquez 144, 28006-Madrid, Spain. Tel: +34-915644562x4247; \\ Fax:+34-915627518; E-mail: aller@cib.csic.es
}

Received 10.10.02; revised 24.2.03; accepted 26.2.03

Edited by G Kroemer

\begin{abstract}
Treatment with $0.2 \mathrm{mM}$ hydrogen peroxide $\left(\mathrm{H}_{2} \mathrm{O}_{2}\right)$ or with $0.5 \mathrm{mM}$ cisplatin caused caspase- 9 and caspase- 3 activation and death by apoptosis in U-937 human promonocytic cells. However, treatment with $2 \mathrm{mM} \mathrm{H}_{2} \mathrm{O}_{2}$, or incubation with the glutathione suppressor DL-buthionine-(S,R)-sulfoximine (BSO) prior to treatment with cisplatin, suppressed caspase activation and changed the mode of death to necrosis. Treatment with $2 \mathrm{mM} \mathrm{H}_{2} \mathrm{O}_{2}$ caused a great decrease in the intracellular ATP level, which was partially prevented by 3 aminobenzamide (3-ABA). Correspondingly, 3-ABA restored the activation of caspases and the execution of apoptosis. By contrast, BSO plus cisplatin did not decrease the ATP levels, and the generation of necrosis by this treatment was not affected by 3-ABA. On the other hand, while all apoptosisinducing treatments and treatment with $2 \mathrm{mM} \mathrm{H}_{2} \mathrm{O}_{2}$ caused Bax translocation from the cytosol to mitochondria as well as cytochrome $c$ release from mitochondria to the cytosol, treatment with BSO plus cisplatin did not. Treatment with cisplatin alone caused Bid cleavage, while $\mathrm{BSO}$ plus cisplatin as well as 0.2 and $2 \mathrm{mM} \mathrm{H}_{2} \mathrm{O}_{2}$ did not. Bcl-2 overexpression reduced the generation of necrosis by $\mathrm{H}_{2} \mathrm{O}_{2}$, but not by BSO plus cisplatin. These results indicate the existence of different apoptosis/necrosis regulatory mechanisms in promonocytic cells subjected to different forms of oxidative stress.

Cell Death and Differentiation (2003) 10, 889-898. doi:10.1038/ sj.cdd. 4401249
\end{abstract}

Keywords: apoptosis; necrosis; $\mathrm{H}_{2} \mathrm{O}_{2}$; cisplatin; glutathione depletion; promonocytic cells

Abbreviations: 3-ABA, 3-aminobenzamide; BSO, DL-buthionine-(S,R)-sulfoximine; cisplatin, CDDP, cis-platinum(II)-diammine dichloride; FCS, fetal calf serum; GSH, reduced glutathione; $\mathrm{H}_{2} \mathrm{O}_{2}$, hydrogen peroxide; mAb, monoclonal antibody; pAb, polyclonal antibody; PARP, poly (ADP-ribose) polymerase; PBS, phosphate-buffered saline; PCD, programmed cell death; PI, propidium iodide; PKC, protein kinase C; ROS, reactive oxygen species

\section{Introduction}

Apoptosis and necrosis were originally described as the two alternative forms of cell death, with well-defined morphological and biochemical differences. Apoptosis, often considered as equivalent to 'programmed cell death' (PCD), was described as the regulated, 'physiological' type of death by which the organism eliminates senescent, abnormal and potentially harmful cells. By contrast, necrosis was described as a passive, nonphysiological type of death caused by cytotoxic insults. ${ }^{1}$ However, this general picture became less clear later because (i) there are forms of PCD with intermediate characteristics between genuine apoptosis and necrosis ${ }^{2,3}$ and (ii) also because cytotoxic agents (such as antitumour drugs, radiation, oxidants and hyperthermia) may provoke cell death with characteristics of apoptosis. ${ }^{4-6}$ In these cases, the mode of death may be often experimentally selected by modifying the conditions of treatment. ${ }^{5,7,8}$ In practical terms, apoptosis (or other forms of apoptosis-like $P C D)^{3}$ is clearly advantageous for the organism since it leads to the elimination of the dying cells by phagocytosis, thus preventing the release of intracellular content and the damage of the surrounding tissue. Hence, it seems very important to elucidate the mechanisms that ultimately decide the adoption of one or the other mode of death.

A factor that may trigger cell death, and that may decide the selection between apoptosis and necrosis, is the increase in intracellular oxidation. Using treatment with exogenous hydrogen peroxide $\left(\mathrm{H}_{2} \mathrm{O}_{2}\right)$ as an experimental paradigm of oxidation, it was often observed that moderate $\mathrm{H}_{2} \mathrm{O}_{2}$ concentrations triggered apoptosis, while elevated concentrations caused necrosis (the exact concentrations depending very much on the used cell model). ${ }^{5,9-11}$ Moreover, the application of a low concentration of exogenous $\mathrm{H}_{2} \mathrm{O}_{2}$ sufficed to suppress apoptosis and cause necrosis-like death in Burkitt's lymphoma cells treated with antitumour drugs. ${ }^{11}$ In this model, the change in the mode of death was attributed to the oxidant-mediated depletion of intracellular ATP, which is a strict requirement for the execution of apoptosis. However, excessive oxidation might also suppress apoptosis by other mechanisms, such as direct inactivation of caspases. ${ }^{10,12} \mathrm{An}$ alternative method to cause oxidation is by decreasing the intracellular concentration of antioxidant molecules, making the cell unable to cope with the normal production of reactive oxygen species (ROS). In this manner, the depletion of intracellular reduced glutathione (GSH) by prolonged incubation with DL-buthionine-( $S, R)$-sulfoximine (BSO), a specific inhibitor of $\gamma$-glutamylcysteine synthetase, caused an in- 
crease in the intracellular content of $\mathrm{H}_{2} \mathrm{O}_{2}$, and potentiated the increase provoked by other treatments. ${ }^{13,14}$ Correspondingly, the incubation with BSO potentiated the lethality of cytotoxic treatments, ${ }^{13-15}$ leading in some cases, to a change of the mode of death from apoptosis to necrosis. 7,16

We have recently reported that the alkylating drug cisplatinum(II)-diammine dichloride (cisplatin, CDDP), which normally caused death by apoptosis, provoked necrosis when applied to U-937 promonocytic cells with a reduced $\mathrm{GSH}$ content. $^{8}$ Although necrosis induction was accompanied by an increased intracellular concentration of peroxides, and could be prevented by antioxidants, it remained unclear whether the change in the mode of death could be adequately explained as the simple consequence of increased ROS accumulation. As a further investigation, in the present work we comparatively analyse some mechanisms critical for the regulation of cell death in U-937 cells subjected to the abovedescribed models of oxidation, namely treatment with exogenous $\mathrm{H}_{2} \mathrm{O}_{2}$, and treatment with cisplatin with and without GSH suppression. The results demonstrate that, among other differences, the switch from apoptosis to necrosis in $\mathrm{H}_{2} \mathrm{O}_{2}$-treated cells is the consequence of ATP depletion, while in BSO plus cisplatin-treated cells it is independent of ATP, and apparently associated with the inhibition of mitochondrial cytochrome $c$ release.

\section{Results}

\section{Death induction and caspase activities}

Figure 1 compares the generation of apoptosis and necrosis in $\mathrm{U}-937$ cells treated with different concentrations of $\mathrm{H}_{2} \mathrm{O}_{2}$, and with cisplatin with and without preincubation with BSO. For quantification, the rate of apoptosis was determined by the frequency of cells with condensed/fragmented chromatin

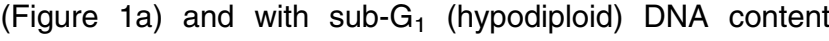
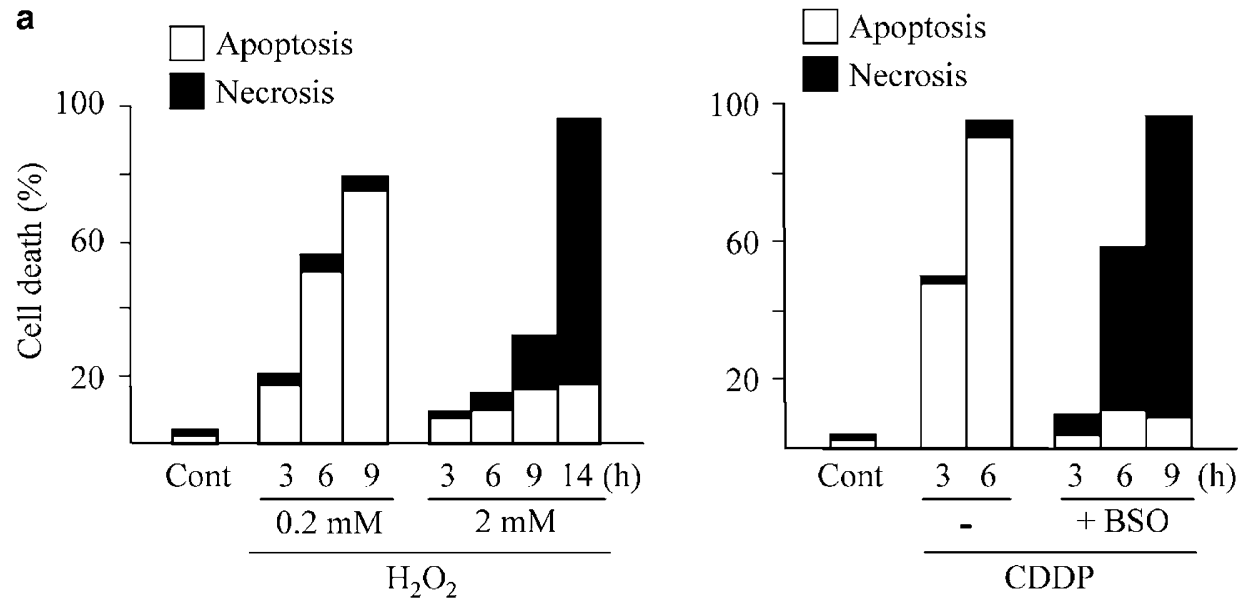

b

Permeabilized Non-permeabilized cells

Cont
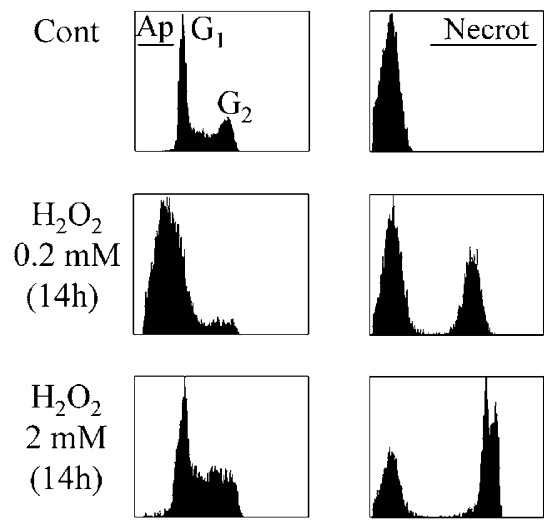

Fluorescence cells

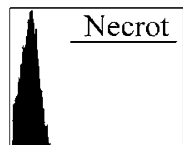

Cont

Permeabilized Non-permeabilized cells cells
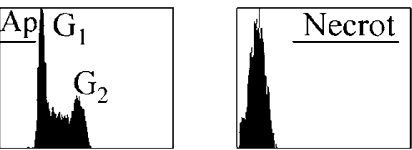

CDDP

(8h)
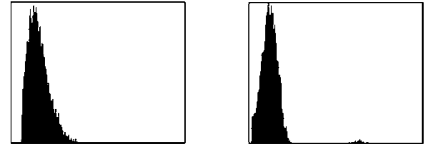

$\mathrm{BSO} /$

CDDP

(8h)
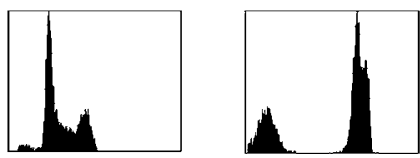

Fluorescence

Figure 1 Generation of apoptosis and necrosis by $\mathrm{H}_{2} \mathrm{O}_{2}$ and cisplatin. (a) Frequency of apoptotic and necrotic cells, as determined by chromatin fragmentation and trypan blue permeability, respectively, in untreated cultures (Cont), in cultures treated for the indicated time periods with the indicated concentrations of $\mathrm{H}_{2} \mathrm{O}_{2}$ and in cultures treated for the indicated time periods with $0.5 \mathrm{mM}$ cisplatin (CDDP), either in the absence (-) or the presence of BSO. BSO (1 mM) was applied $24 \mathrm{~h}$ before treatment with cisplatin. (b) Cell distribution according to PI incorporation into cultures subjected to the indicated treatments, as revealed by flow cytometry. An aliquot of each culture was subjected to permeabilisation (left row in each group), to show the cell cycle distribution and the fraction of apoptotic (sub-G1) cells (Ap), while another aliquot was processed without prior permeabilisation (right row in each group), to determine the fraction of cells which allowed free PI uptake (necrotic). The histograms are representative of one of three (a) or two (b) experiments, with similar results 

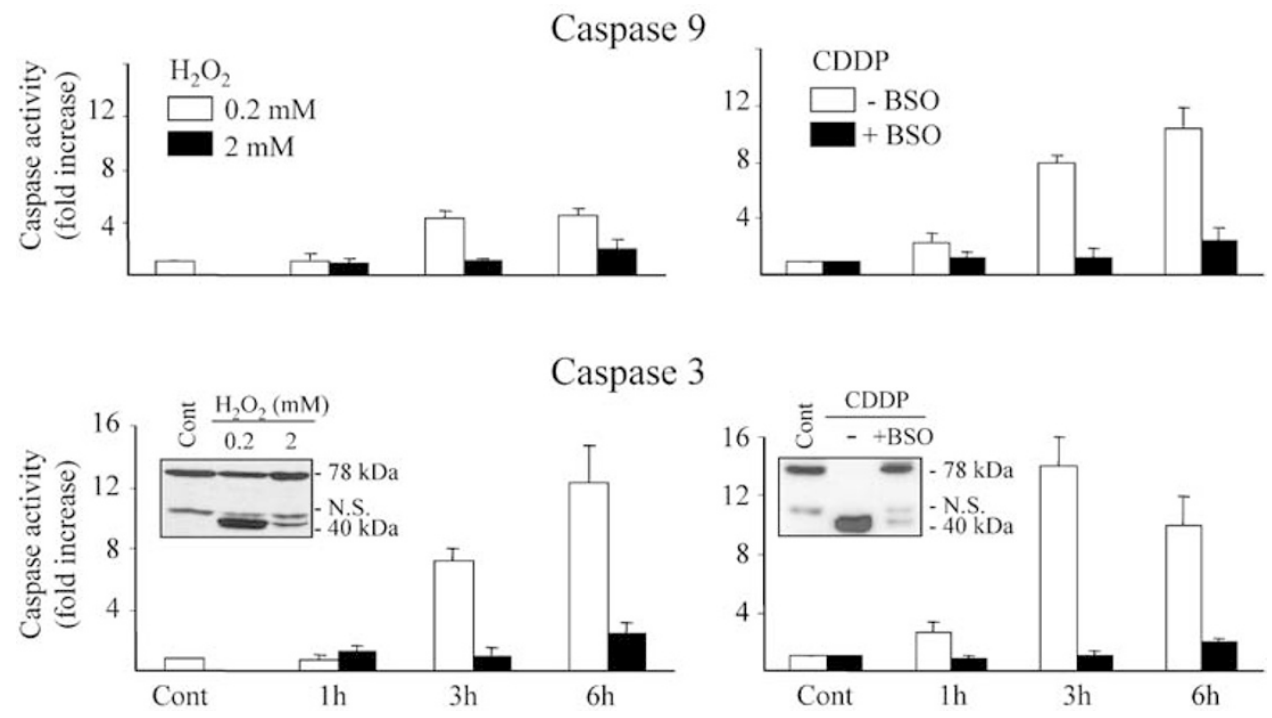

Figure 2 Stimulation of caspase activities. Total cellular extracts (10 $\mu$ g protein per sample) obtained from untreated cells and from cells subjected to the indicated treatments were used to determine the caspase-9 and caspase-3 activities, using as substrates LEHD-pNA and DEVD-pNA, respectively. The results (mean \pm S.D. of three determinations) are represented in relation to untreated cells, which was given the arbitrary value of one. (Insets) PKC $\delta$ cleavage, as determined by immunoblotting, at $6 \mathrm{~h}$ of treatment. The upper band corresponds to the whole protein (approximately $78 \mathrm{kDa}$ ), and the lower band to the main cleavage fragment (approximately $40 \mathrm{kDa}$ ). All other conditions were as in Figure 1

(Figure 1b). The rate of necrosis was determined by the frequency of cells with free penetration of trypan blue (Figure 1a) or propidium iodide (PI) (Figure 1b), indicating plasma membrane damage. In both models, apoptotic cells presented surface blebbing and reduction in size, while necrotic cells exhibited normal chromatin distribution (similar to untreated cells) and cell swelling (results not shown). It was observed that treatment with $0.2 \mathrm{mM} \mathrm{H}_{2} \mathrm{O}_{2}$ only caused apoptosis, while the concentration of $2 \mathrm{mM}$ preferentially caused necrosis. As an exception, the fraction of cells characterised as necrotic in the $0.2 \mathrm{mM} \mathrm{H}_{2} \mathrm{O}_{2}$ treatment in Figure $1 \mathrm{~b}$ probably represents apoptosis-derived 'secondary' necrosis, because of the length of the treatment $(14 \mathrm{~h})$. In these experiments, the execution of necrosis experienced a 5-6 h delay in relation to the execution of apoptosis (see Figure 1a). In addition, it was observed that treatment with $0.5 \mathrm{mM}$ cisplatin alone caused death by apoptosis, but the mode of death was almost totally diverted to necrosis if the treatment was preceded by a $24 \mathrm{~h}$ preincubation with $1 \mathrm{mM}$ BSO. Under these conditions the execution of apoptosis was more rapid, and the delay of necrosis in relation to apoptosis lower (approximately 2-3 h) than in the case of treatments with $\mathrm{H}_{2} \mathrm{O}_{2}$. These differences could not be avoided, since increasing the $\mathrm{H}_{2} \mathrm{O}_{2}$ concentration (from 0.2 to $0.4 \mathrm{mM}$, and from 2 to $6 \mathrm{mM}$ ) did not substantially accelerate the execution of apoptosis and necrosis; and decreasing the cisplatin concentration to 0.05 or $0.1 \mathrm{mM}$ delayed apoptosis, but in this case the combination of BSO plus cisplatin did not produce necrosis (results not shown). A detailed description of other effects of cisplatin and BSO, such as peroxide accumulation, GSH depletion, and changes in mitochondrial transmembrane potential, was already presented in a preceding work, ${ }^{8}$ and hence is omitted here.

The capacity of $\mathrm{H}_{2} \mathrm{O}_{2}$ and cisplatin to cause apoptosis or necrosis, depending on the conditions of treatment, correlated with their capacity to activate the caspase-9/caspase-3 cascade, required for the execution of the 'intrinsic' pathway of apoptosis (the pathway commonly activated by cytotoxic treatments). ${ }^{17}$ Thus, extracts from cells treated with $0.2 \mathrm{mM}$ $\mathrm{H}_{2} \mathrm{O}_{2}$ or cisplatin alone exhibited a marked increase in LEHDase (indicative of caspase-9) and DEVDase (indicative of caspase-3) activities, while these activities were much lower in extracts from cells treated with $2 \mathrm{mM} \mathrm{H}_{2} \mathrm{O}_{2}$ and BSO plus cisplatin (Figure 2). These results were corroborated by the observation that the apoptosis-inducing treatments elicited the typical caspase-3-mediated protein kinase $c$ (PKC) $\delta$ cleavage to give a fragment of approximately $40 \mathrm{kDa},{ }^{18}$ while the cleavage was null or very poor in the case of the necrosis-inducing treatments (see insets in Figure 2).

\section{ATP levels}

Apoptosis is an energy-dependent process, in such a manner that the decrease of ATP below critical levels may impede the execution of apoptosis and promote necrosis. ${ }^{19,20}$ For this reason, experiments were carried out to compare the fluctuations of ATP levels upon treatment with $\mathrm{H}_{2} \mathrm{O}_{2}$ and cisplatin, both under apoptosis and necrosis-inducing conditions. The treatments were carried out for a maximum of $3 \mathrm{~h}$, to prevent possible ATP leakage through the damaged plasma membranes in necrotic cells. The results are indicated in Figure 3. Treatments with $0.2 \mathrm{mM} \mathrm{H}_{2} \mathrm{O}_{2}$ and with cisplatin alone caused a slight decrease in the ATP level, which at $3 \mathrm{~h}$ reached levels of $60-75 \%$ of the control value. Treatment with $2 \mathrm{mM} \mathrm{H}_{2} \mathrm{O}_{2}$ caused a rapid and profound depletion of ATP, which at $1 \mathrm{~h}$ reached levels of around $10 \%$ in relation to control cells. By contrast, BSO plus cisplatin did not decrease, and even augmented the ATP content.

To corroborate the different roles of ATP for the regulation of apoptosis/necrosis induction in the two assayed models, 

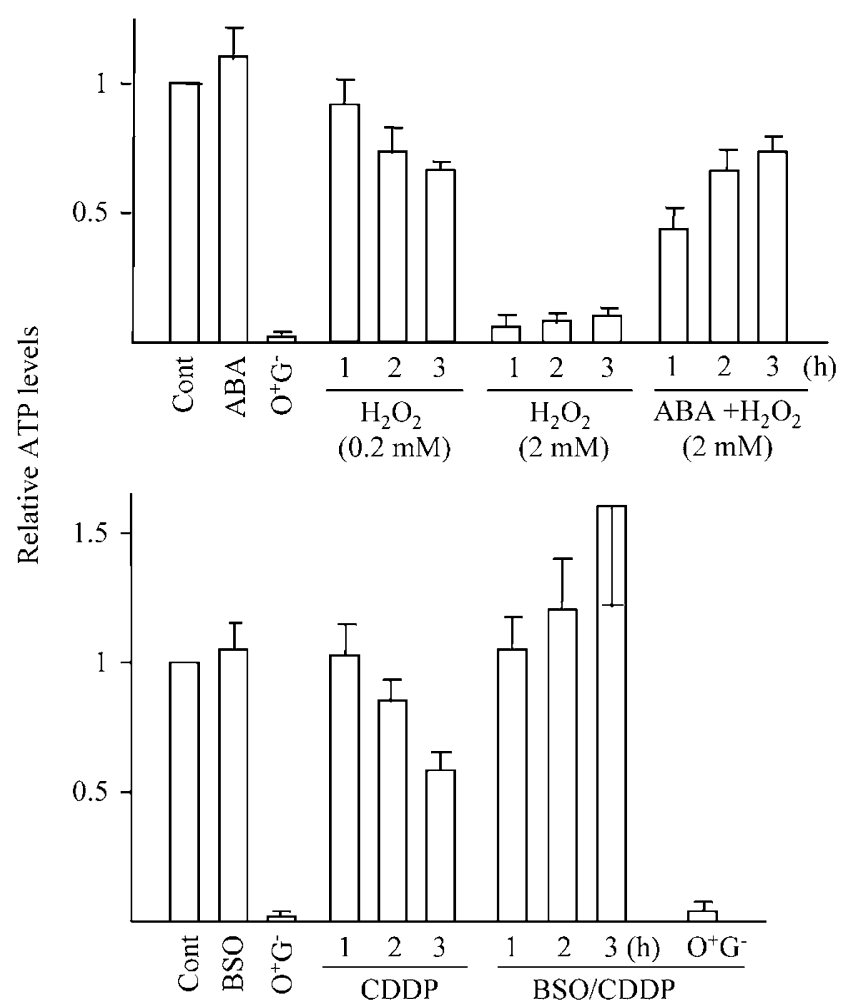

Figure 3 Modulation of ATP levels. The upper histogram shows the relative ATP content in extracts from untreated cells (Cont), from cells treated for $3 \mathrm{~h}$ with 3-ABA alone, and from cells treated for the indicated time periods with 0.2 and $2 \mathrm{mM} \mathrm{H}_{2} \mathrm{O}_{2}$, with and without 3-ABA. The lower histogram shows the relative ATP content in extracts from cells treated with BSO alone, and from cells treated for the indicated time periods with cisplatin, with and without BSO. 3-ABA ( $2.5 \mathrm{mM})$ was added $30 \mathrm{~min}$ before $\mathrm{H}_{2} \mathrm{O}_{2}$. To control the accuracy of the technique, in some experiments the cells were incubated for $3 \mathrm{~h}$ in glucose-free medium supplemented with $10 \mu \mathrm{M}$ oligomycin $\left(\mathrm{O}^{+} \mathrm{G}^{-}\right)$, to suppress all sources of ATP production. The results are the mean + S.D. of at least three determinations. The ATP content in untreated cells was $\left(24.2 \pm 3.1 \mathrm{nmol} / 10^{6}\right.$ cells). All other conditions were as in Figure 1

we examined the effects of the poly (ADP-ribose) polymerase (PARP) inhibitor 3-aminobenzamide (3-ABA). This agent was reported to preserve the ATP pool in cells treated with DNAdamaging agents, preventing the generation of necrosis derived from severe ATP depletion. ${ }^{21,22}$ In agreement with this, we found that 3-ABA partially restored the ATP content in cells treated with $2 \mathrm{mM} \mathrm{H}_{2} \mathrm{O}_{2}$, which in this case maintained a level of at least $40 \%$ in relation to control cells (Figure 3 ). The elevation of ATP levels was accompanied by the suppression of necrosis and the restoration of apoptosis as the mode of death (Figure 4a), and correspondingly by the restoration of the capacity to stimulate caspase- 9 and caspase- 3 activities (Figure 4b). By contrast, 3-ABA did not switch back the mode of death from necrosis to apoptosis nor restore caspase activities in BSO plus cisplatin-treated cells (Figure 4), which as indicated above failed to decrease the intracellular ATP content.

\section{Cytochrome $c$ release}

The release of the cytochrome $c$ from the mitochondria to the cytosol is required for the assembly of the apoptosome and hence for the activation of the caspase cascade in the intrinsic pathway of apoptosis. ${ }^{17}$ However, cytochrome $c$ release is not necessarily a distinctive feature of apoptosis, since it was also occasionally observed in association with necrosis. ${ }^{23-26}$ For these reasons, immunoblot assays were carried out to detect the presence of cytochrome $c$ in cytosolic extracts from cells treated with $\mathrm{H}_{2} \mathrm{O}_{2}$ and cisplatin, under both apoptosis- and necrosis-inducing conditions. As indicated in Figure $5 \mathrm{a}$, cytochrome $c$ could be detected in extracts from cells treated with both 0.2 and $2 \mathrm{mM} \mathrm{H}_{2} \mathrm{O}_{2}$, which caused apoptosis and necrosis, respectively. By contrast, cytochrome $c$ was only detected in extracts from cells treated with cisplatin alone, which caused apoptosis, but not in extracts from cells treated with BSO plus cisplatin, which caused necrosis. The results obtained with cisplatin were confirmed by examining the subcellular distribution of cytochrome $c$ and the mitochondrial $b c_{1}$ complex, by means of immunofluorescence microscopy. Thus, untreated cells and cells treated with BSO plus cisplatin (necrotic) mostly exhibited yellow fluorescence, resulting from the overlapping of the green (indicative of $b c_{1}$ ) and red (indicative of cytochrome $c$ ) signals. By contrast, cells treated with cisplatin alone (apoptotic) clearly exhibited segregated areas of red fluorescence, indicating the presence of cytochrome $c$ outside the mitochondria (Figure $5 b$ ).

\section{Expression of $\mathrm{Bcl}-2$ protein family members}

The release of cytochrome $c$ is regulated by proteins of the Bcl-2 family, which may either inhibit (e.g. the antiapoptotic proteins $\mathrm{Bcl}-2$ and $\mathrm{Bcl}-\mathrm{X}_{\mathrm{L}}$ ) or promote (e.g. the proapoptotic protein Bax) the process. ${ }^{27}$ Bax is normally present as an inactive monomer in the cytosol, and to be functional requires oligomerisation and translocation to the mitochondrial membrane. $^{27}$ In addition, cisplatin and other cytotoxic drugs may stimulate Bid cleavage and insertion into the mitochondrial membrane, where it also promotes cytochrome $c$ release. ${ }^{28,29}$ For these reasons, immunoblot assays were carried out to measure the level, integrity and subcellular distribution of Bcl2, Bcl- $X_{L}, B a x$ and Bid. The results, indicated in Figure 6, were as follows: (i) $\mathrm{Bcl}-2, \mathrm{Bcl}-\mathrm{X}_{\mathrm{L}}$ and $\mathrm{Bax}$ were constitutively expressed in untreated cells, and their total levels were little affected by treatment with $\mathrm{H}_{2} \mathrm{O}_{2}$ and cisplatin, both under apoptosis- and necrosis-inducing conditions (Figure 6a). (ii) In untreated cells, Bax was mostly detected in the cytosolic fraction and only a minimal part in the mitochondrial fraction. Treatment with 0.2 and $2 \mathrm{mM} \mathrm{H}_{2} \mathrm{O}_{2}$ and with cisplatin alone, which as indicated above provoked cytochrome $c$ release, caused a progressive increase (from 2 to $3 \mathrm{~h}$ ) in Bax levels in mitochondrial extracts. By contrast, there was no increase in mitochondrial extracts from cells treated with BSO plus cisplatin, which failed to cause cytochrome $c$ release (Figure $6 \mathrm{~b})$. Bcl-2 was always undetectable in cytosolic fractions (result not shown), and its level in the mitochondrial fractions was not significantly modified by the treatments, being used as an internal control (Figure 6b). (iii) Treatment with cisplatin alone caused a progressive loss (from 2 to $3 \mathrm{~h}$ ) of Bid proform $(21 \mathrm{kDa})$, while treatments with $\mathrm{BSO}$ plus cisplatin and with 0.2 and $2 \mathrm{mM} \mathrm{H}_{2} \mathrm{O}_{2}$ did not (Figure $6 \mathrm{c}$ ). In spite of the commercial specifications of the used antibodies, it was almost impossible to detect Bid fragments by Western blot. 

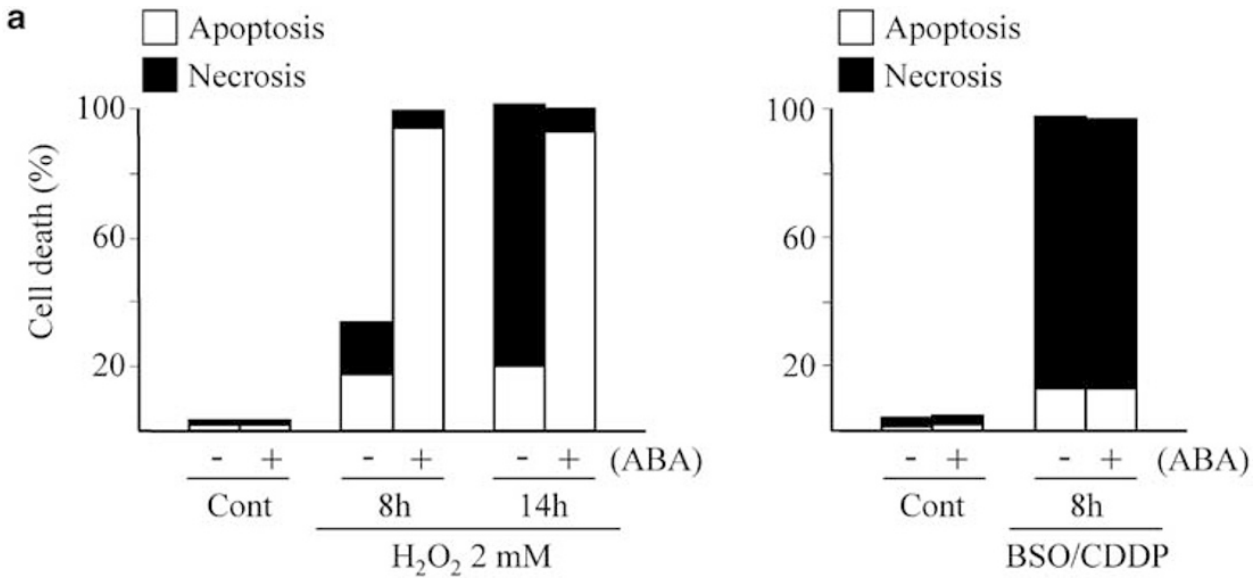

b

Caspase 9
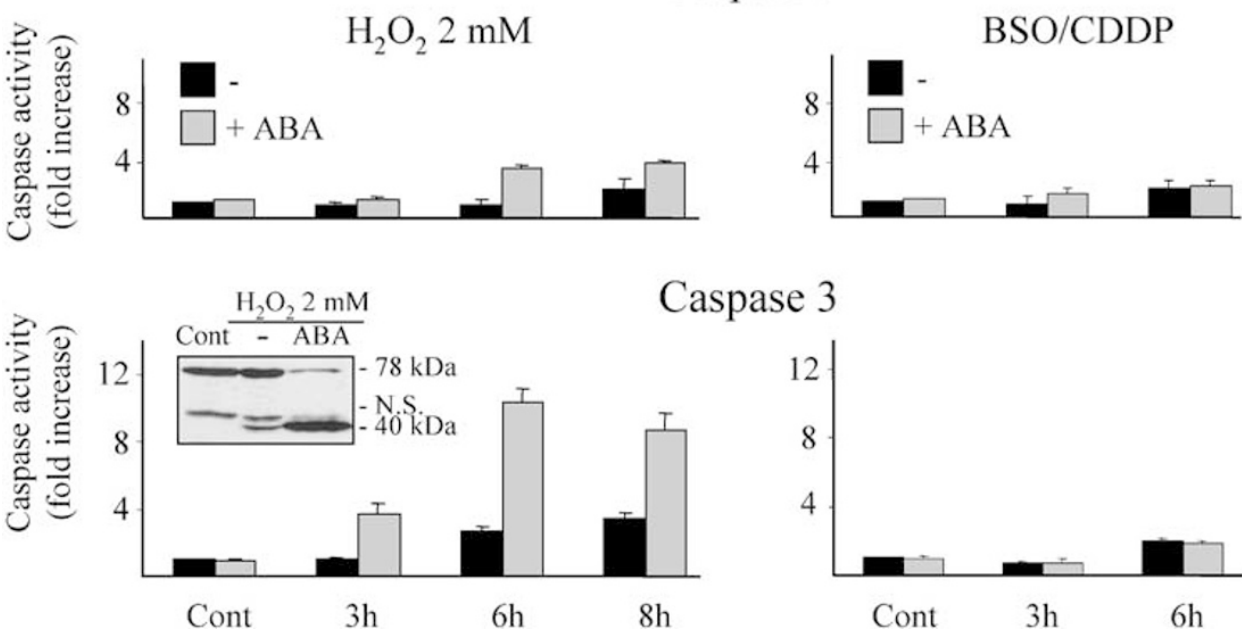

Caspase 3

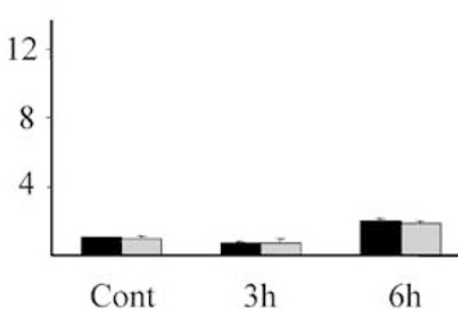

Figure 4 Modulation of cell death and caspase activities by 3-ABA. (a) The histograms show the frequency of apoptotic and necrotic cells, as determined by chromatin fragmentation and trypan blue permeability, respectively, in untreated cultures (Cont) and in cultures treated for the indicated time periods with $2 \mathrm{mM} \mathrm{H}_{2} \mathrm{O}_{2}$ or with $\mathrm{BSO}$ plus cisplatin, either in the absence $(-)$ or the presence $(+)$ of 3-ABA. (b) The histograms show the caspase- 9 and caspase-3 activities in untreated cells (Cont), in cells treated for $6 \mathrm{~h}$ with 3-ABA alone; and in cells treated for the indicated time periods with $2 \mathrm{mM} \mathrm{H}_{2} \mathrm{O}_{2}$ or with $\mathrm{BSO}$ plus cisplatin, with or without 3-ABA. All other conditions were as in Figures $1-3$

Hence, we consider the loss of Bid proform as an indication of cleavage, a criterion also used by other authors. ${ }^{30,31}$

In addition to the well-known action of $\mathrm{Bcl}-2$ as an antiapoptotic factor, some reports indicate that Bcl-2 overexpression may also inhibit necrosis. ${ }^{32-34}$ For this reason, experiments using $\mathrm{Bcl}-2$-transfected U-937 cells were carried out to determine the effect of $\mathrm{Bcl}-2$ overexpression on the generation of necrosis by $2 \mathrm{mM} \mathrm{H}_{2} \mathrm{O}_{2}$ and BSO plus cisplatin. Our control experiments revealed an approximately eight-fold increase in $\mathrm{Bcl}-2$ content in transfected versus nontransfected cells (result not shown). The results are indicated in Figure 7. It was observed that $\mathrm{Bcl}-2$ overexpression decreased the frequency of necrosis following $\mathrm{H}_{2} \mathrm{O}_{2}$ treatment. Of note, this represented an effective cell protection, since the lower frequency of necrosis was not compensated by an increase in the frequency of apoptosis. By contrast, $\mathrm{Bcl}-2$ overexpression did not protect, and even slightly accelerated the generation of necrosis by BSO plus cisplatin. As expected, $\mathrm{Bcl}-2$ overexpression greatly inhibited apoptosis induction by treatment with $0.2 \mathrm{mM} \mathrm{H}_{2} \mathrm{O}_{2}$ and cisplatin alone (result not shown).

\section{Discussion}

The results in this work corroborate earlier observations indicating that $\mathrm{H}_{2} \mathrm{O}_{2}$ causes apoptosis or necrosis, depending on the concentration used, ${ }^{5,9,10}$ and that the depletion of intracellular GSH diverts the mode of death from apoptosis to necrosis in cells treated with cisplatin and other alkylating agents. ${ }^{8,16}$ Since one of the main functions of GSH is to act as a ROS scavenger, GSH depletion may cause per se an overaccumulation of $\mathrm{H}_{2} \mathrm{O}_{2}$ and/or potentiate its accumulation by treatment with cytotoxic agents, as we had in fact demonstrated to occur in the case of cisplatin. ${ }^{8}$ Hence, one could hypothesise that the mechanism(s) that regulate cell death upon treatment with BSO plus cisplatin are the same one(s) operating upon treatment with high $\mathrm{H}_{2} \mathrm{O}_{2}$ 


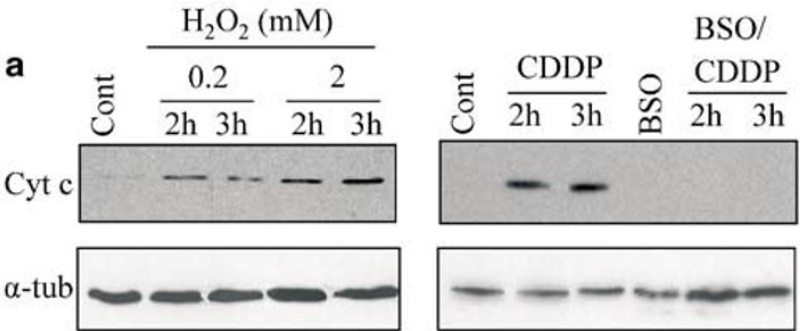

b
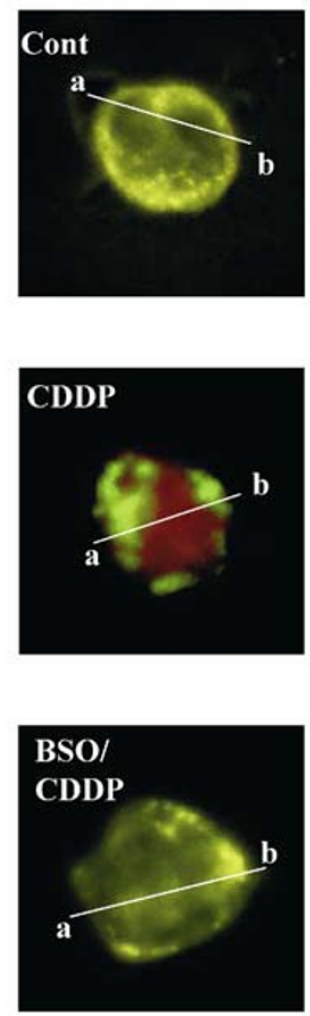

a

a

b a
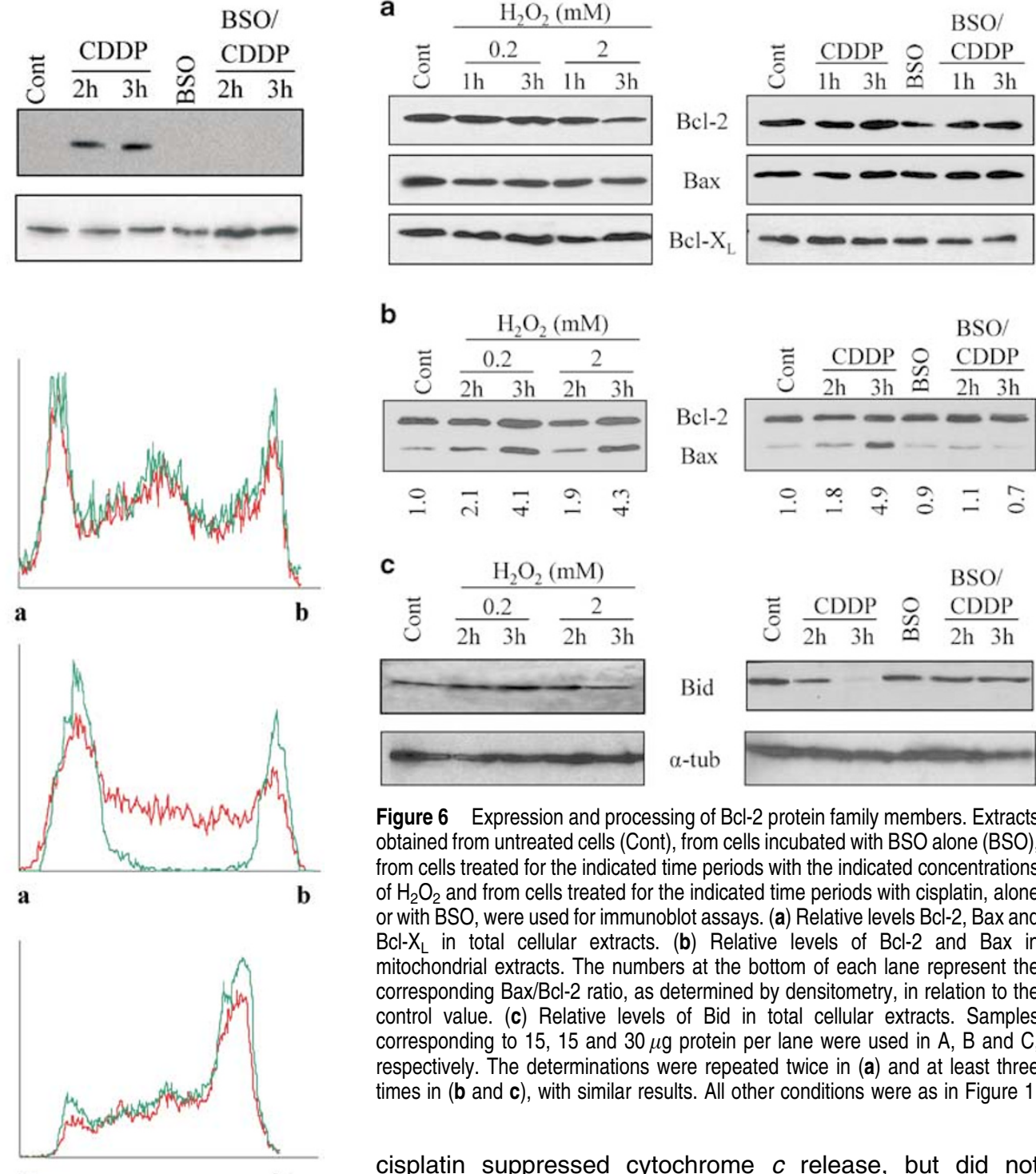

Figure 5 Cytochrome $c$ release. (a) Cytosolic extracts ( $25 \mu \mathrm{g}$ protein per lane) obtained from untreated cells (Cont), from cells incubated with BSO alone (BSO), from cells treated for the indicated time periods with the indicated concentrations of $\mathrm{H}_{2} \mathrm{O}_{2}$ and from cells treated for the indicated time periods with cisplatin, with or with $\mathrm{BSO}$, were used to measure the relative level of cytochrome $c$ by means of immunoblotting. The level of $\alpha$-tubulin was also measured as a control. The blots are representative of one of four experiments with similar results. (b) Untreated cells (Cont), and cells treated for $3 \mathrm{~h}$ with cisplatin, with or without BSO, were fixed and processed for immunolocalisation of cytochrome $\mathrm{C}$ and mitochondrial $b c_{1}$ complex. The yellow fluorescence indicates colocalisation of $b c_{1}$ (green signal) and cytochrome $c$ (red signal), while the red fluorescence in CDDP indicates segregation of cytochrome $c$. The graphs indicate the distribution of fluorescence in sections of the cells (the orientation given by a and $b$ ). All other conditions were as in Figure 1

concentrations. Actually, both treatments were unable to activate the caspase- $9 / 3$ cascade, characteristic of the mitochondrial pathway of apoptosis. However, the mechanisms responsible for caspase inhibition, and hence for the suppression of apoptosis, are not coincident. Thus, while $2 \mathrm{mM} \mathrm{H}_{2} \mathrm{O}_{2}$ greatly decreased the intracellular ATP content, but allowed cytochrome $c$ release to the cytosol, BSO plus

b
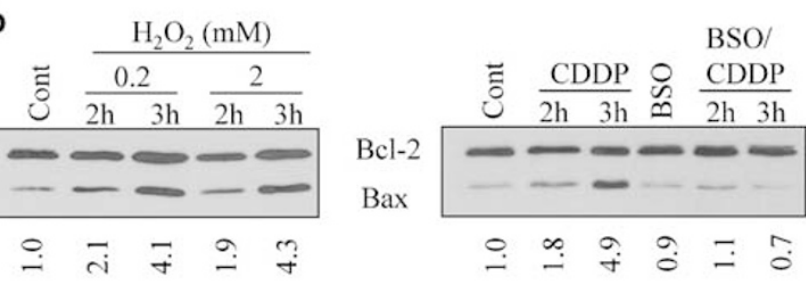

C

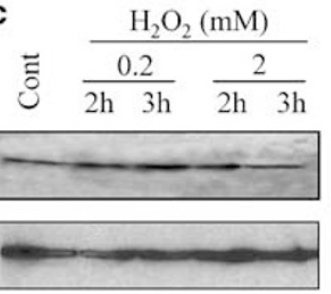

$\mathrm{BSO} /$

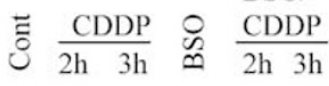

Bid

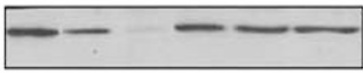

$\alpha-$ tub

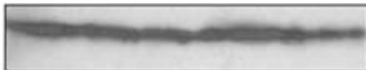

Figure 6 Expression and processing of $\mathrm{Bcl}-2$ protein family members. Extracts obtained from untreated cells (Cont), from cells incubated with BSO alone (BSO), from cells treated for the indicated time periods with the indicated concentrations of $\mathrm{H}_{2} \mathrm{O}_{2}$ and from cells treated for the indicated time periods with cisplatin, alone or with BSO, were used for immunoblot assays. (a) Relative levels Bcl-2, Bax and $\mathrm{Bcl}-\mathrm{X}_{\mathrm{L}}$ in total cellular extracts. (b) Relative levels of Bcl-2 and Bax in mitochondrial extracts. The numbers at the bottom of each lane represent the corresponding Bax/Bcl-2 ratio, as determined by densitometry, in relation to the control value. (c) Relative levels of Bid in total cellular extracts. Samples corresponding to 15,15 and $30 \mu$ g protein per lane were used in A, B and C, respectively. The determinations were repeated twice in (a) and at least three times in ( $\mathbf{b}$ and $\mathbf{c}$ ), with similar results. All other conditions were as in Figure 1

cisplatin suppressed cytochrome $c$ release, but did not decrease ATP.

The inability of $2 \mathrm{mM} \mathrm{H}_{2} \mathrm{O}_{2}$ to cause apoptosis may be explained by the sharp reduction in ATP levels, which impedes the assembly of the apoptosome and hence caspase activation. ${ }^{17}$ In addition, the lack of ATP could directly cause necrosis by preventing the functioning of a plasma membrane-associated $\mathrm{Na}^{+} / \mathrm{K}^{+}$ATPase normally active during apoptosis, with the consequence of ionic unbalance, water uptake, and cell swelling and lysis. ${ }^{35}$ The minimum content of intracellular ATP compatible with the execution of apoptosis has been estimated in approximately $25 \%$ of the normal value. ${ }^{20}$ Our results fit with this estimation, since (i) $0.2 \mathrm{mM}$ $\mathrm{H}_{2} \mathrm{O}_{2}$ only caused a slight (approximately $25 \%$ ) reduction in ATP levels and generated apoptosis; (ii) $2 \mathrm{mM} \mathrm{H}_{2} \mathrm{O}_{2}$ reduced the ATP level by approximately $90 \%$ and caused necrosis and (iii) 3-ABA restored the ATP level to approximately $40-50 \%$ of control values and restored apoptosis. These latter results could be explained by changes in the activity of PARP, a molecule recently characterised as a critical switch between apoptosis and necrosis. ${ }^{36}$ Thus, the oxidative stress caused by elevated $\mathrm{H}_{2} \mathrm{O}_{2}$ concentrations may generate extensive 
a
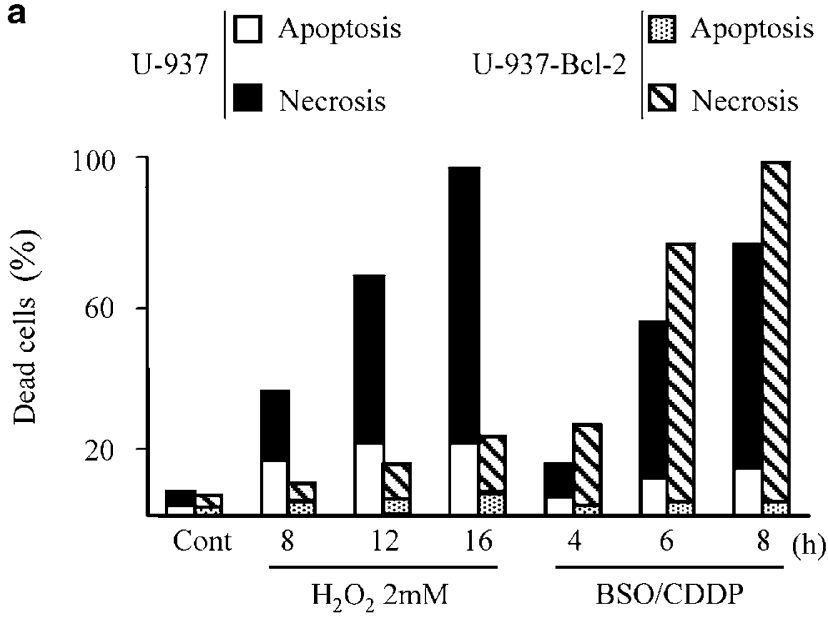

b
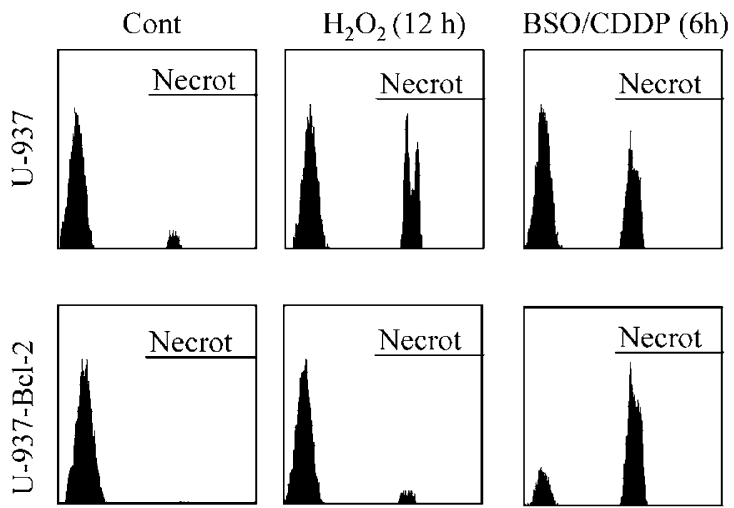

Fluorescence intensity

Figure 7 Effect of $\mathrm{Bcl}-2$ overexpression on the generation necrosis (a) Frequency of apoptotic and necrotic cells, as determined by chromatin fragmentation and trypan blue permeability, respectively, in nontransfected (U937) and Bcl-2-transfected (U-937-Bcl-2) cell cultures treated for the indicated time periods with the $2 \mathrm{mM} \mathrm{H}_{2} \mathrm{O}_{2}$ or with $\mathrm{BSO}$ plus cisplatin. (b) Frequency of necrotic cells using the same cell types and treatments, as revealed by $\mathrm{PI}$ penetration and flow cytometry. The values were repeated three times (a) and twice (b) with similar results. All other conditions were as in Figure 1

DNA damage, leading to PARP activation, $\mathrm{NAD}^{+}$consumption and massive ATP depletion. ${ }^{37}$ Under these conditions, the administration of 3-ABA may inhibit PARP activation, partially preserving the ATP pool. Alternatively or complementarily, $\mathrm{H}_{2} \mathrm{O}_{2}$ might suppress the de novo ATP synthesis by inhibiting mitochondrial respiration and/or glycolytic enzyme activities $^{38}$ and 3-ABA could preserve ATP by preventing the block of glycolysis. ${ }^{39}$ Whatever the case, it seems clear that the generation of necrosis by BSO plus cisplatin is independent of ATP, as far as the treatment did not reduce the ATP level, and necrosis was not prevented by 3-ABA.

Another manner in which $\mathrm{H}_{2} \mathrm{O}_{2}$ could suppress apoptosis is by direct inactivation of caspases, because of the oxidation of the cysteine residues in their catalytic sites ${ }^{10}$ (although this mechanism has been challenged). ${ }^{40}$ This was apparently the case in menadione-treated HepG2 cells, where menadione increased oxidation, decreased ATP levels and caused necrosis, but necrosis could not be prevented by the elevation of ATP. ${ }^{12}$ However, this mechanism does not seem to operate in our model, since the increase of ATP levels by 3-ABA sufficed to restore caspase activities and apoptosis. Of note, we and others have reported that the administration of the pancaspase inhibitor Z-VAD-Fmk prevented the execution of apoptosis in U-937 cells. ${ }^{8,41,42}$ However, in this case the suppression of apoptosis was not accompanied by cell swelling, and plasma membrane integrity was only affected at approximately $24 \mathrm{~h}$ (i.e. much later than in our present experiments). This may be in agreement with reports indicating that caspase inhibition per se might be insufficient to cause classical necrosis. ${ }^{3}$ Hence, the generation of necrosis under oxidant conditions (treatment with $\mathrm{H}_{2} \mathrm{O}_{2}$ or GSH depletion) probably involves additional physiological disturbances, for example, ionic unbalance, as indicated above.

The inability of BSO plus cisplatin to activate the caspase cascade and hence to cause apoptosis may be adequately explained by the lack of cytochrome $c$ release from mitochondria to the cytosol; and the lack of cytochrome $c$ release could be the consequence, at least in part, of the lack of Bax translocation to mitochondria. Actually, there was always a correlation between Bax translocation and cytochrome $c$ release in the two types of treatments used, $\mathrm{H}_{2} \mathrm{O}_{2}$ and cisplatin. In addition, Bid might participate in the regulation of cytochrome $c$ release in cisplatin-treated cells, since cisplatin alone caused Bid cleavage (as deduced from the disappearance of the $21 \mathrm{kDa}$ proform), while BSO plus cisplatin did not. Noteworthy, $\mathrm{H}_{2} \mathrm{O}_{2}$ failed to stimulate Bid processing under all used conditions, a result also reported by other authors. ${ }^{31}$ The disparity in the behaviour of Bid might indicate that, in addition to necrosis, apoptosis is also differentially regulated in cells subjected to $\mathrm{H}_{2} \mathrm{O}_{2}$ and cisplatin. Finally, although no attempts were made to examine the influence of $\mathrm{Bcl}-2$ expression on cytochrome $c$ release, the experiments using Bcl-2-transfected cells lead to interesting results. On the one hand, $\mathrm{Bcl}-2$ overexpression reduced the generation of both apoptosis and necrosis by $\mathrm{H}_{2} \mathrm{O}_{2}$. This was not surprising, since one of the earlier described actions of $\mathrm{Bcl}-2$ is to activate antioxidant functions in the cell, ${ }^{43,44}$ and other reports also indicated inhibition by $\mathrm{Bcl}-2$ of necrosis induction by $\mathrm{H}_{2} \mathrm{O}_{2}$ and other cytotoxic treatments. ${ }^{32-34}$ By contrast, $\mathrm{Bcl}-2$ overexpression did not reduce, and even facilitated the generation of necrosis by BSO plus cisplatin. This result was unexpected, since Bcl-2 was reported to counteract the increase in toxicity generated by GSH depletion. ${ }^{44,45} \mathrm{~A}$ full understanding of these results requires a deeper investigation, but meanwhile they reinforce the conclusion of a different regulation of necrosis induction by $\mathrm{H}_{2} \mathrm{O}_{2}$ and $\mathrm{BSO}$ plus cisplatin.

Although one of the roles of GSH is the scavenging of peroxides, GSH also regulates other important aspects of the redox equilibrium. For instance, glutathione may form reversible mixed disulphides with protein thiols, preventing irreversible oxidation of cysteine residues under oxidative stress. ${ }^{46}$ Hence, the lack of GSH upon prolonged treatment with BSO could compromise this defensive function. In addition, the lack of GSH may result in an increase in the intracellular free, acting concentration of alkylating drugs, since these drugs are detoxified by GSH conjugation. ${ }^{47}$ This is also important, since cisplatin is a very reactive molecule, which directly binds nucleophilic sites of many cellular components, including proteins. ${ }^{48}$ In these ways, BSO plus 
cisplatin could severely alter the function of proteins critical for apoptosis-necrosis regulation - such as Bcl-2 family members (as demonstrated here in the case of Bax) and/or mitochondrial permeability transition pore constituents. ${ }^{49}$ This might explain the existence of substantial differences in the regulation of cell death by different forms of oxidative stress namely, direct treatment with $\mathrm{H}_{2} \mathrm{O}_{2}$ versus $\mathrm{GSH}$ depletion.

\section{Materials and Methods}

\section{Chemicals}

All components for cell culture were obtained from Life Technologies, Inc. (Gaithersburg, MD, USA). 4,6-diamidino-2-phenylindole was obtained from Serva (Heidelberg, Germany); RNase A from Roche Diagnostics, S.L. (Barcelona, Spain); digitonin, caspase-3 substrate I, (Ac-DEVD-pNA) and caspase-9 substrate II (LEHD-pNA) from Calbiochem (Darmstadt, Germany); and 3-ABA, BSO, DL-dithiothreitol, cisplatin, oligomycin, PI and protease inhibitor cocktail from Sigma (Madrid, Spain). Mouse anti-human $\mathrm{Bcl}-2$ (100) monoclonal antibody (mAb), rabbit anti-human Bax (N-20) polyclonal antibody (pAb), and rabbit anti-human nPKC $\delta$ (C-20) pAb were from Santa Cruz Biotechnology, Inc. (Santa Cruz, CA, USA). Rabbit antihuman $\mathrm{Bcl}-\mathrm{X}_{\mathrm{L}} \mathrm{pAb}$ was from Transduction Laboratories (Lexington, $\mathrm{KY}$, USA). Mouse anti-pigeon cytochrome $c \mathrm{mAb}$ (clone $7 \mathrm{H} 8.2 \mathrm{C} 12$, used for immunoblot assays) and mouse anti-rat cytochrome $\mathrm{cmAb}$ (clone 6H2.B4, used for immunofluorescence microscopy) were from BD PharMingen (San Diego, CA, USA). Goat anti-human Bid (C-20) and goat anti-mouse Bid pAbs were obtained from Santa Cruz Biotechnology and R\&D Systems, Inc. (Wiesbaden-Nordenstad, Germany). Mouse anti-human COX II was obtained from Molecular Probes (Eugene, OR, USA). Rabbit anti-rat $b c_{1}$ complex was a generous gift of Professor R Bisson, Padova, Italy. Mouse anti-chicken $\alpha$-tubulin mAb, fluorescein isothiocyanateconjugated goat anti-rabbit IgG, and tetramethylrhodamine isothiocyanate-conjugated goat anti-mouse IgG were from Sigma. Peroxidaseconjugated rabbit anti-mouse IgG and peroxidase-conjugated goat antirabbit IgG were from DAKO Diagnósticos, S.A. (Barcelona, Spain).

\section{Cell culture and treatments}

U-937 human promonocytic leukemia cells, ${ }^{50}$ and Bcl-2-transfected U-937 cells (kindly provided by Dr. Jacqueline Bréard, INSERM 461, Chatenay Malabry, France) were grown in RPMl 1640 supplemented with 10\% (v/v) heat-inactivated fetal calf serum (FCS), and $0.2 \%$ sodium bicarbonate and antibiotics in a humidified $5 \% \mathrm{CO}_{2}$ atmosphere at $37^{\circ} \mathrm{C}$. 4,6-diamidino-2phenylindole $(10 \mathrm{mg} / \mathrm{ml})$ and $\mathrm{PI}(1 \mathrm{mg} / \mathrm{ml})$ were dissolved in phosphatebuffered saline (PBS), and cisplatin $(3.3 \mathrm{mM})$ in distilled water. These solutions were stored at $4^{\circ} \mathrm{C}$. 3-ABA $(100 \mathrm{mM})$ was dissolved in distilled water and stored at $-20^{\circ} \mathrm{C}$. BSO $(50 \mathrm{mM})$ was freshly prepared in distilled water, just before use. Typically, the cells were seeded at $2 \times 10^{5} \mathrm{cell} / \mathrm{s} / \mathrm{ml}$ $24 \mathrm{~h}$ before treatment with cisplatin or $\mathrm{H}_{2} \mathrm{O}_{2}$. For GSH depletion, the cells were incubated for $24 \mathrm{~h}$ with $1 \mathrm{mM} \mathrm{BSO}$, before treatment with cisplatin. Under these conditions BSO caused an approximately $70 \%$ reduction in total GSH content, but did not affect cell proliferation or viability. To obtain a complete ATP depletion, the cells were incubated in the presence of $10 \mu \mathrm{M}$ oligomycin in glucose-free RPMI medium, supplemented with $1 \mathrm{mM}$ sodium pyruvate and $10 \%(\mathrm{v} / \mathrm{v})$ dialysed FCS.

\section{Determination of apoptosis and necrosis}

To analyse changes in nuclear morphology, the cells were collected by centrifugation, washed with PBS, resuspended in PBS and mounted on glass slides. After fixation in $70 \%(\mathrm{v} / \mathrm{v})$ ethanol, the cells were stained for $20 \mathrm{~min}$ at room temperature in PBS containing $1 \mu \mathrm{g} / \mathrm{ml} \mathrm{4,6-diamidino-2-}$ phenylindole and examined by fluorescence microscopy. Apoptosis was characterised by chromatin condensation followed by partition into multiple bodies. Within the experimental time periods used in this work, nonapoptotic, primary necrotic cells still exhibited diffuse and uniform chromatin staining, as untreated cells. To measure loss of DNA, cells were collected by centrifugation and incubated for $30 \mathrm{~min}$ in PBS containing $0.5 \mathrm{mg} / \mathrm{ml}$ RNase $A$ and $0.1 \%(\mathrm{w} / \mathrm{v})$ Nonidet P-40. After the addition of PI (final concentration of $50 \mu \mathrm{g} / \mathrm{ml}$ ), the cells were analysed by flow cytometry. Late apoptotic cells exhibited sub-G $\mathrm{G}_{1} \mathrm{PI}$ incorporation (hypodiploid cells). Within the experimental time periods used in this work, nonapoptotic, primary necrotic cells did not exhibit significant loss of DNA, nor significant alterations in the cell cycle distribution in relation to untreated cells.

The criterion currently used to examine necrosis was the loss of membrane integrity, as measured by massive influx of either trypan blue or $\mathrm{PI}$ in nonpermeabilised cells. In the first case, cells were incubated for 5 min with $0.2 \%(\mathrm{w} / \mathrm{v})$ trypan blue and examined by microscopy using a Neubauer haemacytometer. Under these conditions, only necrotic cells were clearly stained. In the second case, nonpermeabilised cells were suspended in PBS containing $50 \mu \mathrm{g} / \mathrm{ml} \mathrm{PI}$, and the fluorescence was analysed by flow cytometry. Under these conditions only necrotic cells exhibited great fluorescence, while the fluorescence was null or very low in apoptotic cells.

\section{Caspase activity assays}

Samples of $4 \times 10^{6}$ cells were collected by centrifugation, washed twice with ice-cold PBS, resuspended in $50 \mu$ l of ice-cold lysis buffer (1 mM DLdithiothreitol, $0.03 \%$ Nonidet P-40 (v/v), in $50 \mathrm{mM}$ Tris $\mathrm{pH} 7.5$ ), kept on ice for $30 \mathrm{~min}$ and finally centrifuged at $14000 \times \mathrm{g}$ for $15 \mathrm{~min}$ at $4^{\circ} \mathrm{C}$. Samples containing aliquots of the supernatants (corresponding to $10 \mu \mathrm{g}$ of total protein), $8 \mu \mathrm{l}$ of the appropriate caspase substrate (Ac-DEVD-pNA for caspase-3, and LEHD-pNA for caspase-9), and PBS to complete $200 \mu \mathrm{l}$, were prepared by triplicate in 96-well microtiter plates, and incubated for $1 \mathrm{~h}$ at $37^{\circ} \mathrm{C}$. The absorption was measured by spectrometry at $405 \mathrm{~nm}$.

\section{Measurement of ATP levels}

To estimate the intracellular ATP content, aliquots of $2 \times 10^{6}$ cells were collected in a preheated $\left(70^{\circ} \mathrm{C}\right)$ buffer consisting of $100 \mathrm{mM}$ Tris and $4 \mathrm{mM}$ EDTA, pH 8, and heated for $2 \mathrm{~min}$ at $100^{\circ} \mathrm{C}$. After cooling on ice and centrifugation at $10000 \times g$ for $1 \mathrm{~min}$ at $4^{\circ} \mathrm{C}$, the ATP content in the supernatants was determined using an ATP Bioluminescence Assay Kit CLSII (Roche Diagnostics, Barcelona, Spain), following the procedure indicated by the manufacturer, and a TD-20/29 luminometer (Turner Designs, Sunnyvale, CA, USA). ATP standard curves (linear in the range of 5-500 nM) were carried out in all experiments. Extracts from cells depleted of ATP by incubation with oligomycin-containing glucose-free medium were routinely used as control of the technique.

\section{Protein extraction, subcellular fractionation and immunoblot assays}

To obtain total cellular protein extracts, samples of $3 \times 10^{6}$ cells were collected by centrifugation, washed with PBS and lysed by 5 min heating at $100^{\circ} \mathrm{C}$ in Laemmli's buffer containing protease inhibitors followed by sonication. To obtain cytosolic extracts for the determination of 
cytochrome $c$ release, samples of $3 \times 10^{6}$ cells were collected by centrifugation, and permeabilised for $5 \mathrm{~min}$ in $100 \mu \mathrm{l}$ of ice-cold PBS containing $80 \mathrm{mM} \mathrm{KCl}, 250 \mathrm{mM}$ sucrose and $200 \mu \mathrm{g} / \mathrm{ml}$ digitonin. After centrifugation, the pellet was discarded and the supernatant used for immunoblotting. Control determinations using anti-COX II antibody revealed that the supernatants were free of mitochondrial contamination. To obtain mitochondrial and cytosolic extracts for the determination of Bax localisation, the subcellular fractionation procedure described by Kim et al..$^{51}$ was followed, with minor modifications. Samples of $10^{7}$ cells were washed with PBS and resuspended in $300 \mu$ l of solution A $(20 \mathrm{mM}$ HEPES-KOH, pH.7.5, $10 \mathrm{mM} \mathrm{KCl}, 1.5 \mathrm{mM} \mathrm{MgCl}_{2}, 1 \mathrm{mM}$ EDTA, $1 \mathrm{mM}$ EGTA, $1 \mathrm{mM}$ dithiothreitol, supplemented with $250 \mathrm{mM}$ sucrose and protease inhibitors). The cells were lysed by passing them five times through a 25-gauge needle, after which the homogenates were centrifuged for $10 \mathrm{~min}$ at $1000 \mathrm{~g}$ at $4^{\circ} \mathrm{C}$ to remove unbroken cells, nuclei and large membrane fragments. The upper part of the supernatant (approximately $200 \mu \mathrm{l}$ ) was carefully removed and centrifuged for $20 \mathrm{~min}$ at $10000 \times g$ at $4^{\circ} \mathrm{C}$. The resulting pellet (mitochondrial fraction) was washed with solution $A$, centrifuged again, and solubilised by heating and sonication in Lammli's buffer containing protease inhibitors. The resulting supernatant was centrifuged for $1 \mathrm{~h}$ at $100000 \mathrm{~g}$ at $4^{\circ} \mathrm{C}$ to obtain the cytosolic fraction. Control experiments using anti-COX II and anti- $\alpha$-tubulin antibodies were carried out to check the purity of mitochondrial and cytosolic fractions. In all cases, the detection of specific proteins either in the total cellular extracts or in the cell fractions was carried out by immunoblot, following the previously described procedure. ${ }^{52}$

\section{Immunofluorescence microscopy}

U-937 cells immobilised on slides were processed for simultaneous detection of cytochrome $c$ and $b c_{1}$, following the earlier described procedure. $^{53}$

\section{Acknowledgements}

This work was supported in part by Grant SAF-2001-1219 from the Plan Nacional de Investigacion Científica, Desarrollo e Investigación Tecnológica, Ministerio de Ciencia y Tecnología; by Grant 01/0946 from the Fondo de Investigación Sanitaria, Ministerio de Sanidad y Consumo; and by Grant 08.3/0011.3/2001 from the Comunidad Autónoma de Madrid, Spain, to PA; by the Associazione Italiana per la Ricerca sul Cancro (AIRC, Italy) to PB; and by the Program of Cooperation between the CSIC (Spain) and the CNR (Italy). AT and CF are recipients of predoctoral fellowships from the Ministerio de Ciencia y Tecnología, and PS of a predoctoral fellowship from the Ministerio de Educación, Cultura y Deporte, Spain. We thank Professors J Bréard and R Bisson for providing Bcl-2-transfected U-937 cells and anti-bc $c_{1}$ complex antibody, respectively.

\section{References}

1. Wyllie AH, Kerr JF and Currie AR (1980) Cell death: the significance of apoptosis. Int. Rev. Cytol. 68: 251-306

2. Kitanaka $C$ and Kuchino $Y$ (1999) Caspase-independent programmed cell death with necrotic morphology. Cell Death Differ. 6: 508-515

3. Leist $M$ and Jäättelä $M$ (2001) Four deaths and a funeral: from caspases to alternative mechanisms. Nat. Rev. Mol. Cell Biol. 2: 589-598

4. Haimovitz-Friedman A, Khan CC, Ehleiter D, Persaud RS McLoughlin M, Fuks $Z$ and Kolesnick RN (1994) lonizing radiation acts on cellular membranes to generate ceramide and initiate apoptosis. J. Exp. Med. 180: 525-535
5. Nosseri C, Coppola S and Ghibelli L (1994) Possible involvement of poly(ADPribosyl) polymerase in triggering stress-induced apoptosis. Exp. Cell Res. 212: 367-373

6. Mesner Jr PW, Budihardjo II and Kaufmann SH (1997) Chemotherapy-induced apoptosis. In Apoptosis: Pharmacological Implications and Therapeutic Opportunities, Kaufmann S (ed) San Diego, London, Boston, New York, Sydney, Tokyo, Toronto: Academic Press pp. 461-469.

7. Galán A, Troyano A, Vilaboa NE, Fernández C, De Blas E and Aller P (2001) Modulation of the stress response during apoptosis and necrosis induction in cadmium-treated U-937 human promonocytic cells. Biochim. Biophys. Acta 1538: 38-46

8. Troyano A, Fernández C, Sancho P, De Blas E and Aller P (2001) Effect of glutathione depletion on antitumor drug toxicity (apoptosis and necrosis) in U937 human promonocytic cells. The role of intracellular oxidation. J. Biol. Chem. 276: 47107-47115

9. Gardner AM, Xu FH, Fady C, Jacoby FJ, Duffey DC, Tu Y and Lichtenstein A (1997) Apoptotic vs. nonapoptotic cytotoxicity induced by hydrogen peroxide. Free Radical Biol. Med. 22: 73-83

10. Hampton MB and Orrenius S (1997) Dual regulation of caspase activity by hydrogen peroxide: implications for apoptosis. FEBS Lett. 414: 552-556

11. Lee YJ and Shacter E (1999) Oxidative stress inhibits apoptosis in human lymphoma cells. J. Biol. Chem. 274: 19792-19798

12. Samali A, Nordgren H, Zhivotovsky B, Peterson E and Orrenius S (1999) A comparative study of apoptosis and necrosis in HepG2 cells: oxidant-induced caspase inactivation leads to necrosis. Biochem. Biophys. Res. Commun. 255: 6-11

13. Miyajima A, Nakashima J, Yoshioka K, Tachibana M, Tazaki $H$ and Murai $M$ (1997) Role of reactive oxygen species in cis-dichlorodiammineplatinuminduced cytotoxicity on bladder cancer cells. Br. J. Cancer 76: 206-210

14. McGowan AJ, Bowie AG, O'Neill LA and Cotter TG (1998) The production of a reactive oxygen intermediate during the induction of apoptosis by cytotoxic insult. Exp. Cell Res. 238: 248-256

15. Bailey HH (1998) L-S,R-buthionine sulfoximine: historical development and clinical issues. Chem. Biol. Interact. 1111-12: 239-254

16. Fernandes RS and Cotter TG (1994) Apoptosis or necrosis: intracellular levels of glutathione influence the mode of cell death. Biochem. Pharmacol. 48: 675681

17. Adrain C and Martin SJ (2001) The mitochondrial apoptosome: a killer unleashed by the cytochrome seas. Trends Biochem. Sci. 26: 390-397

18. Ghayur T, Hugunin M, Talanian RV, Ratnofsky S, Quinlan C, Emoto Y, Pandey P, Datta R, Huang Y, Kharbanda S, Allen H, Kamen R, Wong W and Kufe D (1996) Proteolytic activation of protein kinase $\mathrm{C} \delta$ by an ICE/CED3-like protease induces characteristics of apoptosis. J. Exp. Med. 184: 2399-2404

19. Eguchi $Y$, Shimizu S and Tsujimoto $Y$ (1997) Intracellular ATP levels determine the cell death fate by apoptosis or necrosis. Cancer Res. 57: 1835-1840

20. Leist M, Single B, Castoldi AF, Kuhnle S and Nicotera P (1997) Intracellular adenosine triphosphate (ATP) concentration: a switch in the decision between apoptosis and necrosis. J. Exp. Med. 185: 1481-1486

21. Filipovic DM, Meng $X$ and Reeves WB (1999) Inhibition of PARP prevents oxidant-induced necrosis but not apoptosis in LLC-PK1 cells. Am. J. Physiol. 277: F428-F436

22. Cole KK and Pérez-Polo JR (2002) Poly(ADP-ribose) polymerase inhibition prevents both apoptotic-like delayed neuronal death and necrosis after $\mathrm{H}_{2} \mathrm{O}_{2}$ injury. J. Neurochem. 82: 19-29

23. Atlante A, Calissano P, Bobba A, Azzariti A, Marra E and Passarella S (2000) Cytochrome $c$ is released from mitochondria in a reactive oxygen species (ROS)-dependent fashion and can operate as a ROS scavenger and as a respiratory substrate in cerebellar neurons undergoing excitotoxic death. J. Biol. Chem. 275: 37159-37166

24. Kim YM, Chung HT, Simmons RL and Billiar TR (2000) Cellular non-heme iron content is a determinant of nitric oxide-mediated apoptosis, necrosis and caspase inhibition. J. Biol. Chem. 275: 10954-10961

25. Lee RH, Song JM, Park MY, Kang SK, Kim YK and Jung JS (2001) Cisplatininduced apoptosis by translocation of endogenous Bax in mouse collecting duct cells. Biochem. Pharmacol. 62: 1013-1023

26. Single B, Leist M and Nicotera $P$ (2001) Differential effects of Bcl-2 on cell death triggered under ATP-depleting conditions. Exp. Cell. Res. 262: 8-16

27. Adams JM and Cory S (2001) Life-or-death decisions by the Bcl-2 protein family. Trends Biochem. Sci. 26: 61-66 
28. Slee EA, Keogh SA and Martin SJ (2000) Cleavage of BID during cytotoxic drug and UV radiation-induced apoptosis occurs downstream of the point of Bcl-2 action and is catalyzed by caspase-3: a potential feedback loop for amplification of apoptosis-associated mitochondrial cytochrome $c$ release. Cell Death Differ. 7: 556-565

29. Mandic A, Viktorsson K, Strandberg L, Heiden T, Hansson J, Linder S and Shoshan MC (2002) Calpain-mediated Bid cleavage and calpain-independent Bak modulation: two separate pathways of cisplatin-induced apoptosis. Mol. Cell. Biol. 22: 3003-3013

30. Zhuang S, Demirs JT and Kochevar IE (2000) p38 mitogen-activated protein kinase mediates bid cleavage, mitochondrial dysfunction, and caspase-3 activation during apoptosis induced by singlet oxygen but not by hydrogen peroxide. J. Biol. Chem. 275: 25939-25948

31. Kulms D, Zeise E, Pöppelmann B and Schwarz T (2002) DNA damage, death receptor activation and reactive oxygen species contribute to ultraviolet radiation-induced apoptosis in an essential independent way. Oncogene 21: 5844-5851

32. Shimizu S, Eguchi $Y$, Kamike W, Waguri S, Uchiyama $Y$, Matsuda $H$ and Tsujimoto $Y$ (1996) Retardation of chemical hypoxia-induced necrotic cell death by Bcl-2 and ICE inhibitors: possible involvement of common mediators in apoptotic and necrotic signal transduction. Oncogene 12: 2045-2050

33. Guénal I, Sidoti-de Fraisse C, Gaumer S and Mignotte B (1997) Bcl-2 and Hsp27 act at different levels to suppress programmed cell death. Oncogene 15 : 347-360

34. Denecker G, Vercammen D, Steemans M, Vanden Berghe T, Brouckaert G, Van Loo G, Zhivotovsky B, Fiers W, Grooten J, Declercq W and Vandenabeele $P$ (2001) Death receptor-induced apoptotic and necrotic cell death: differential role of caspases and mitochondria. Cell Death Differ. 8: 829-840

35. Barros LF, Hermosilla T and Castro J (2001) Necrotic volume increase in the early physiology of necrosis. Comp. Biochem. Physiol. A 130: 401-409

36. Los M, Mozoluk M, Ferrari D, Stepczynska A, Stroh A, Renz A, Herzeg Z, Wang $Z Q$ and Schulze-Osthoff $K$ (2002). Activation and caspase-mediated inhibition of PARP: a molecular switch between fibroblast necrosis and apoptosis in death receptor signaling. Mol. Biol. Cell 13: 978-988

37. Schraufstatter IU, Hinshaw DB, Hyslop PA, Spragg RG and Cochrane CG (1986) Oxidant injury of cells. DNA strand-breaks activate polyadenosine diphosphate-ribose polymerase and lead to depletion of nicotinamide adenine dinucleotide. J. Clin. Invest. 77: 1312-1320

38. Hyslop PA, Hinshaw DB, Halsey JR WA, Schraufstatter IU, Sauerheber RD, Spragg RG, Jackson JH and Cochrane CG (1988) Mechanisms of oxidantmediated cell injury. The glycolytic and mitochondrial pathways of ADP phosphorylation are major intracellular targets inactivated by hydrogen peroxide. J. Biol. Chem. 263: 1665-1675
39. Colussi C, Albertini MC, Coppola S, Rovidati S, Galli F and Ghibelli L (2000) $\mathrm{H}_{2} \mathrm{O}_{2}$-induced block of glycolysis as an active ADP-ribosylation reaction protecting cells from apoptosis. FASEB J. 14: 2266-2276

40. Lee YJ and Shacter $E(2000)$ Hydrogen peroxide inhibits activation, not activity, of cellular caspase-3 in vivo. Free Radical Biol. Med. 29: 684-692

41. Galán A, García-Bermejo L, Troyano A, Vilaboa NE, Fernández C, De Blas E and Aller $P$ (2001) The role of intracellular oxidation in death induction (apoptosis and necrosis) in human promonocytic cells treated with stress inducers (cadmium, heat, X-rays). Eur. J. Cell Biol. 80: 312-320

42. Okada $Y$ and Maeno $E$ (2001) Apoptosis, cell volume regulation and volumeregulatory chloride channels. Comp. Biochem. Physiol. A 130: 377-383

43. Hockenbery DM, Oltvai ZN, Yin XM, Milliman CL and Korsmeyer SJ (1993) $\mathrm{Bcl}-2$ functions in an antioxidant pathway to prevent apoptosis. Cell 75: 241-251

44. Kane DJ, Sarafian TA, Anton R, Hahn H, Gralla EB, Valentine JS, Ord T and Bredesen DE (1993) Bcl-2 inhibition of neural death: decreased generation of reactive oxygen species. Science 262: 1274-1277

45. Vahrmeijer AL, Hoetelmans RW, Mulder GJ, Schutrups J, Van Vlierberghe RL, Van de Velde CJ and Van Dierendonck JH (2000) Development of resistance to glutathione depletion-induced cell death in CC531 colon carcinoma cells: association with increased expression of bcl-2. Biochem. Pharmacol. 59: 1557-1562

46. Cotgreave IA and Gerdes RG (1998) Recent trends in glutathione biochemistry - glutathione-protein interactions: a molecular link between oxidative stress and cell proliferation?. Biochem. Biophys. Res. Commun. 242: 1-9

47. Tew KD (1994) Glutathione-associated enzymes in anticancer drug resistance. Cancer Res. 54: 4313-4320

48. Jamieson ER and Lippard SJ (1999) Structure, recognition, and processing of cisplatin-DNA adducts. Chem. Rev. 99: 2467-2498

49. Bernardi P (1999) Mitochondrial transport of cations: channels, exchangers, and permeability transition. Physiol. Rev. 79: 1127-1155

50. Sundström C and Nilsson K (1976) Establishment and characterization of a human histiocytic lymphoma cell line (U-937). Int. J. Cancer 17: 565-577

51. Kim HJ, Mun JY, Chun YJ, Choi KH and Kim MY (2001) Bax-dependent apoptosis induced by ceramide in HL-60 cells. FEBS Lett. 505: 264-268

52. Galán A, García-Bermejo ML, Troyano A, Vilaboa NE, De Blas E, Kazanietz $M G$ and $P$. Aller $P(2000)$ Stimulation of p38 mitogen-activated protein kinase is an early regulatory event for the cadmium-induced apoptosis in human promonocytic cells. J. Biol. Chem. 275: 11418-11424

53. Petronilli V, Penzo D, Scorrano L, Bernardi $P$ and Di Lisa $F(2001)$ The mitochondrial permeability transition, release of cytochrome $c$ and cell death. Correlation with the duration of pore openings in situ. J. Biol. Chem. 276: 12030-12034 